\title{
Gene Expression of Type VI Secretion System Associated with Environmental Survival in Acidovorax avenae subsp. avenae by Principle Component Analysis
}

\section{Zhouqi Cui ${ }^{1, \dagger}$, Guoqiang Jin ${ }^{2, \dagger}$, Bin Li ${ }^{1, *}$, Kaleem Ullah Kakar ${ }^{1}$, Mohammad Reza Ojaghian ${ }^{1}$, Yangli Wang ${ }^{3}$, Guanlin Xie ${ }^{1}$ and Guochang Sun ${ }^{3, *}$}

1 State Key Laboratory of Rice Biology, Institute of Biotechnology, Zhejiang University, Hangzhou 310058, China; E-Mails: twelue@163.com (Z.C.); k_khan_2009@yahoo.com (K.U.K.); smro59@gmail.com (M.R.O.); glxie@zju.edu.cn (G.X.)

2 Yuhang Extension and Service Center of Agriculture Technical, Hangzhou 311100, China;

E-Mail:wzli@126.com

3 State Key Laboratory Breeding Base for Zhejiang Sustainable Plant Pest and Disease Control, Key Laboratory of Detection for Pesticide Residues, Ministry of Agriculture, Zhejiang Academy of Agricultural Sciences, Hangzhou 310021, China;

E-Mail: ylwang88@aliyun.com

$\dagger$ These authors contributed equally to this work.

* Authors to whom correspondence should be addressed; E-Mails: 1ibin0571@zju.edu.cn (B.L.); sungc01@sina.com (G.S.); Tel./Fax: +86-571-8898-1412 (B.L.); +86-571-8641-9061 (G.S.).

Academic Editor: Patrick C.Y. Woo

Received: 8 June 2015 / Accepted: 18 August 2015 / Published: 11 September 2015

\begin{abstract}
Valine glycine repeat G (VgrG) proteins are regarded as one of two effectors of Type VI secretion system (T6SS) which is a complex multi-component secretion system. In this study, potential biological roles of T6SS structural and VgrG genes in a rice bacterial pathogen, Acidovorax avenae subsp. avenae (Aaa) RS-1, were evaluated under seven stress conditions using principle component analysis of gene expression. The results showed that growth of the pathogen was reduced by $\mathrm{H}_{2} \mathrm{O}_{2}$ and paraquat-induced oxidative stress, high salt, low temperature, and $\operatorname{vgr} G$ mutation, compared to the control. However, pathogen growth was unaffected by co-culture with a rice rhizobacterium Burkholderia seminalis R456. In addition, expression of 14 T6SS structural and eight vgrG
\end{abstract}


genes was significantly changed under seven conditions. Among different stress conditions, high salt, and low temperature showed a higher effect on the expression of T6SS gene compared with host infection and other environmental conditions. As a first report, this study revealed an association of T6SS gene expression of the pathogen with the host infection, gene mutation, and some common environmental stresses. The results of this research can increase understanding of the biological function of T6SS in this economically-important pathogen of rice.

Keywords: T6SS gene expression; gene knockout; co-culture; in vivo; stress; principle component analysis

\section{Introduction}

Secretion of proteins through secretion systems is a way by which bacteria influence their extracellular surroundings and other bacteria [1]. In pathogenic bacteria, the secretion systems which transfer proteins and toxins into the environment and within a eukaryotic target cell are important for their virulence and survival in hosts [2,3]. At least six distinct multi-component secretion systems (referred to type I-VI secretion system, or T1SS-T6SS) are used by Gram-negative bacterial pathogens to transport the proteins across the membranes of the bacteria and, eventually, the host [4-8]. The T6SS is a newly found multi-component secretion system, which is often involved in interaction with eukaryotic hosts in either pathogenic or symbiotic relationships [9]. According to previous studies, most of T6SS-containing bacteria are known as human and animal pathogens [7,10]. The T6SS encoded by clusters of contiguous genes is composed of 13 conserved proteins and a variable complement of accessory elements. It is reported that they are present in one or more copies in numerous Gram-negative bacterial pathogens including Vibrio cholerae, Pseudomonas aeruginosa, Yersinia pestis, Escherichia coli, Salmonella enterica, Agrobacterium tumefaciens, Rhizobium leguminosarum, Francisellatularensis, Burkholderia mallei, and Edwardsiella spp. In addition, the T6SS genes have key roles in virulence-related processes in some of these bacterial pathogens [11-18].

In bacterial pathogens, infection of the host depends on effective colonization, as well as survival, of the pathogen in the host and environment by resistance against different stress conditions [19-21]. Researchers have shown that T6SS plays an important role in pathogens to show resistance to environmental stresses [22-24]. For example, pppA-ppkA null mutant decreased resistance to $\mathrm{H}_{2} \mathrm{O}_{2}$-induced oxidative stress of $P$. aeruginosa [25]. Weber et al. (2009) reported a new role for T6SS in the ecology of Vibrio anguillarum and attributed this role to a signal-sensing mechanism that modulates expression of regulators of the general stress response [26]. These results indicate that there is a potential interaction between stress conditions and T6SS genes in bacterial pathogens of human and animals.

Recently, T6SSs of plant pathogens such as Pseudomonas syringae and Pectobacterium wasabiae have been studied [27-29]. Furthermore, genome-wide analysis revealed the existence of only one T6SS gene cluster in strain RS-1 of Acidovorax avenae subsp. avenae (Aaa), a widely-distributed seed-borne pathogen of rice [30]. In addition, our previous study showed that the homolog of $\mathrm{VgrG}$, as one of two most important putative T6SS effectors, cannot be encoded by a T6SS cluster but it is considered as an orphan 
component in Aaa RS-1 [31]. The objective of this study was to assess the potential interaction between expression of T6SS structure and VgrG genes of Aaa RS-1 and common environmental stress conditions, including in vivo infection, co-culture with rice rhizobacterium Burkholderia seminalis R456, and one $\operatorname{vgr} G$ (Aave_0497) mutation, as well as high salt, low-temperature, $\mathrm{H}_{2} \mathrm{O}_{2}$ - and paraquat-induced stresses.

\section{Results}

\subsection{Repression of Bacterial Growth under Environmental Stress Conditions}

The growth of Aaa strain RS-1 was significantly inhibited by high salt, low temperature, $\mathrm{H}_{2} \mathrm{O}_{2}$ - and paraquat-mediated oxidative stress compared to the corresponding control. The survival of Aaa RS-1 under conditions of high salt, low temperature, $\mathrm{H}_{2} \mathrm{O}_{2}$ and paraquat stress is shown in Figure 1. Results from this study indicated that nutrient broth (NB) supplemented with $2.0 \%$ and $3.0 \% \mathrm{NaCl}$ caused a reduction for $66.1 \%$ and $83.1 \%$, respectively, in the growth of Aaa RS-1 compared to the control $(1.0 \% \mathrm{NaCl})$. No statistical difference was observed among the concentrations of $\mathrm{NaCl}$ higher than $3.0 \%$ (Figure 1a). Compared to $30{ }^{\circ} \mathrm{C}$ (control), low temperature at $15{ }^{\circ} \mathrm{C}$ caused a $27.1 \%, 71.2 \%$, and $75.9 \%$ reduction in the growth of Aaa RS-1 after 6, 12, and 24 h, respectively (Figure 1b). Furthermore, $\mathrm{H}_{2} \mathrm{O}_{2}$ at 8, 16, and $32 \mathrm{mM}$ caused a significant reduction of $73.0 \%, 98.2 \%$, and $98.2 \%$, respectively, in the growth of Aaa RS-1 (Figure 1c). Paraquat at 10, 50, and $100 \mu \mathrm{M}$ caused a $16.0 \%, 58.0 \%$, and $61.8 \%$ reduction, respectively, in the growth of Aaa RS-1 after $24 \mathrm{~h}$ compared to the control. The growth of Aaa RS-1 was unaffected by $10 \mu \mathrm{M}$ of paraquat, but was significantly reduced by 50 and $100 \mu \mathrm{M}$ of paraquat (Figure 1d). In addition, NB supplemented with $2.0 \% \mathrm{NaCl}$, culture at $15^{\circ} \mathrm{C}$, NB supplemented with $8 \mathrm{mM} \mathrm{H}_{2} \mathrm{O}_{2}$ and $\mathrm{NB}$ supplemented with $50 \mu \mathrm{M}$ paraquat for $24 \mathrm{~h}$ were selected as repression points for salt-induced osmotic stress, low temperature stress, $\mathrm{H}_{2} \mathrm{O}_{2}$-induced oxidized stress, and paraquat-induced oxidized stress, respectively.

\subsection{Repression of Bacterial Growth during in Vivo Infection and Co-Culture Condition}

We did not count the number of bacteria during in vivo infection and did not compare with the number of bacteria cultured under in vitro condition because the bacterial density is obviously higher in the broth in vitro than in the plants in vivo. Furthermore, the growth of Aaa strain RS-1 was unaffected by the co-culture of bacteria with $B$. seminalis $\mathrm{R} 456$. The OD 600 value increased from 0.2 to 1.4 when bacteria were incubated in NB alone, while the OD 600 value increased from 0.2 to 1.1 after $24 \mathrm{~h}$ at $30^{\circ} \mathrm{C}$ when bacteria were co-cultured in NB with B. seminalis R456.

\subsection{Repression of Bacterial Growth in $\Delta v g r G-2$}

There was a significant difference in the growth between the wild type and the $\Delta v g r G-2$ of Aaa strain RS-1. The OD 600 of wild type increased from 0.089 to $0.545,0.910$, and 1.348 after 12,24 , and $48 \mathrm{~h}$ of incubation at $30^{\circ} \mathrm{C}$, respectively. However, the $\mathrm{OD}_{600}$ of $\Delta v g r G$-2 was significantly inhibited by $50.6 \%, 57.1 \%$, and $52.7 \%$ compared to the wild type after 12,24 , and $48 \mathrm{~h}$ of incubation at $30{ }^{\circ} \mathrm{C}$, respectively. There was no significant difference in the growth between the wild type and complementary strain $\Delta v g r G$-2(vgrG-2). In addition, there was no significant difference in the growth between the mutant strain and mock strain $\Delta v g r G-2($ pRADK) (Figure 2). 
a
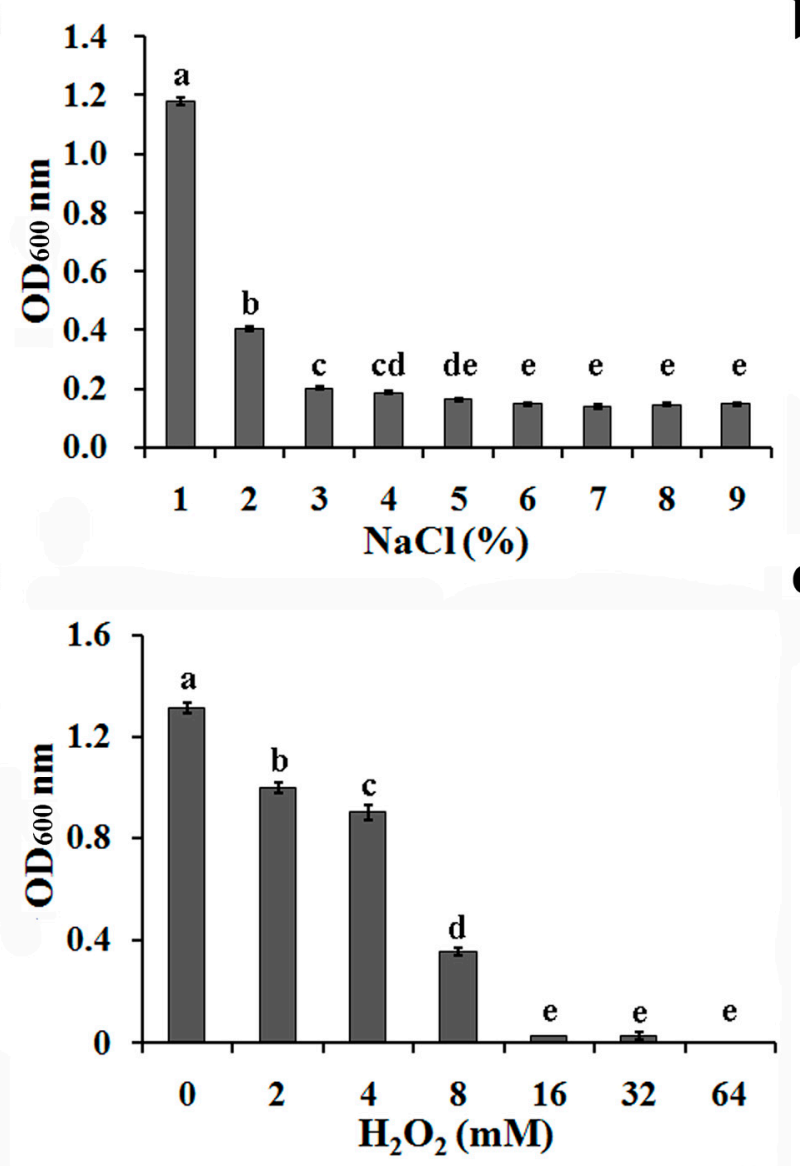

b

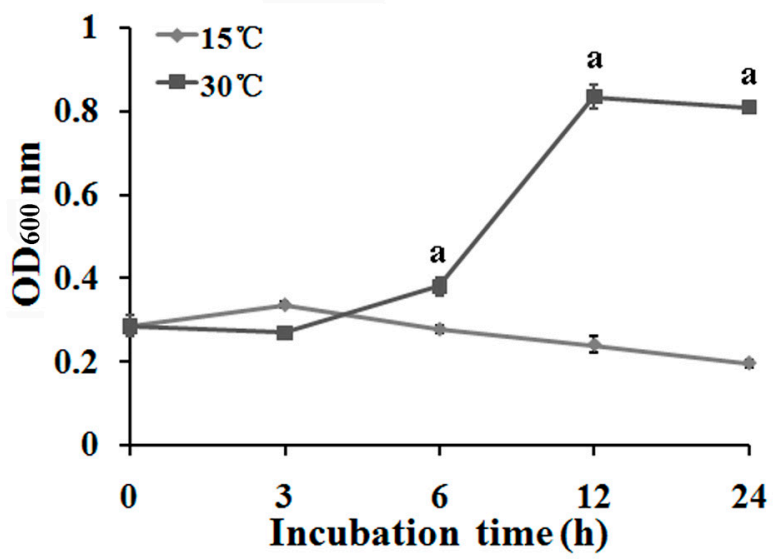

d

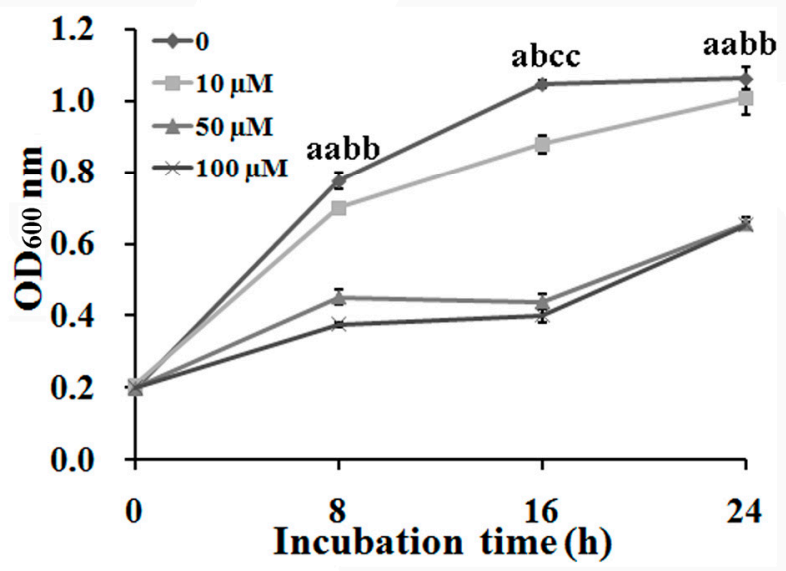

Figure 1. Growth of Acidovorax avenae subsp. avenae RS-1 under different conditions of (a) $\mathrm{NaCl}$-induced osmotic stress; (b) low temperature stress; (c) $\mathrm{H}_{2} \mathrm{O}_{2}$-mediated oxidative stress; (d) paraquat-mediated oxidative stress $(p<0.05)$. Aaa RS-1 incubated in NA broth with $1.0 \% \mathrm{NaCl}$ at $30{ }^{\circ} \mathrm{C}, 200 \mathrm{rpm}$ for $24 \mathrm{~h}$ was used as the negative control. Data from the repeated experiment were pooled and subjected to analysis of variance. Columns with the same letters $(\mathrm{a}-\mathrm{e})$ are not significantly different $(p=0.05)$. Error bars represent the standard error of the mean.

\subsection{No Significant Difference for in Vitro Expression of T6SS Gene}

Gene expression data obtained from quantitative real-time PCR (qPCR) showed that the $\Delta C_{\mathrm{t}}$ values of 22 T6SS genes (14 structural genes and eight $\operatorname{vgr} G$ genes) in NB (control) samples varied from 16.4 to $30.2\left(\Delta C_{\mathrm{t}}\right)$ (Figure 3). This suggested that there was a slight difference in the gene expression of each T6SS component under in vitro condition. However, in general, this result revealed that the expression level of 22 different T6SS genes under in vitro condition was similar for this change is less than two-fold, which have been regarded as the standard to differentiate significant change from insignificant change. 


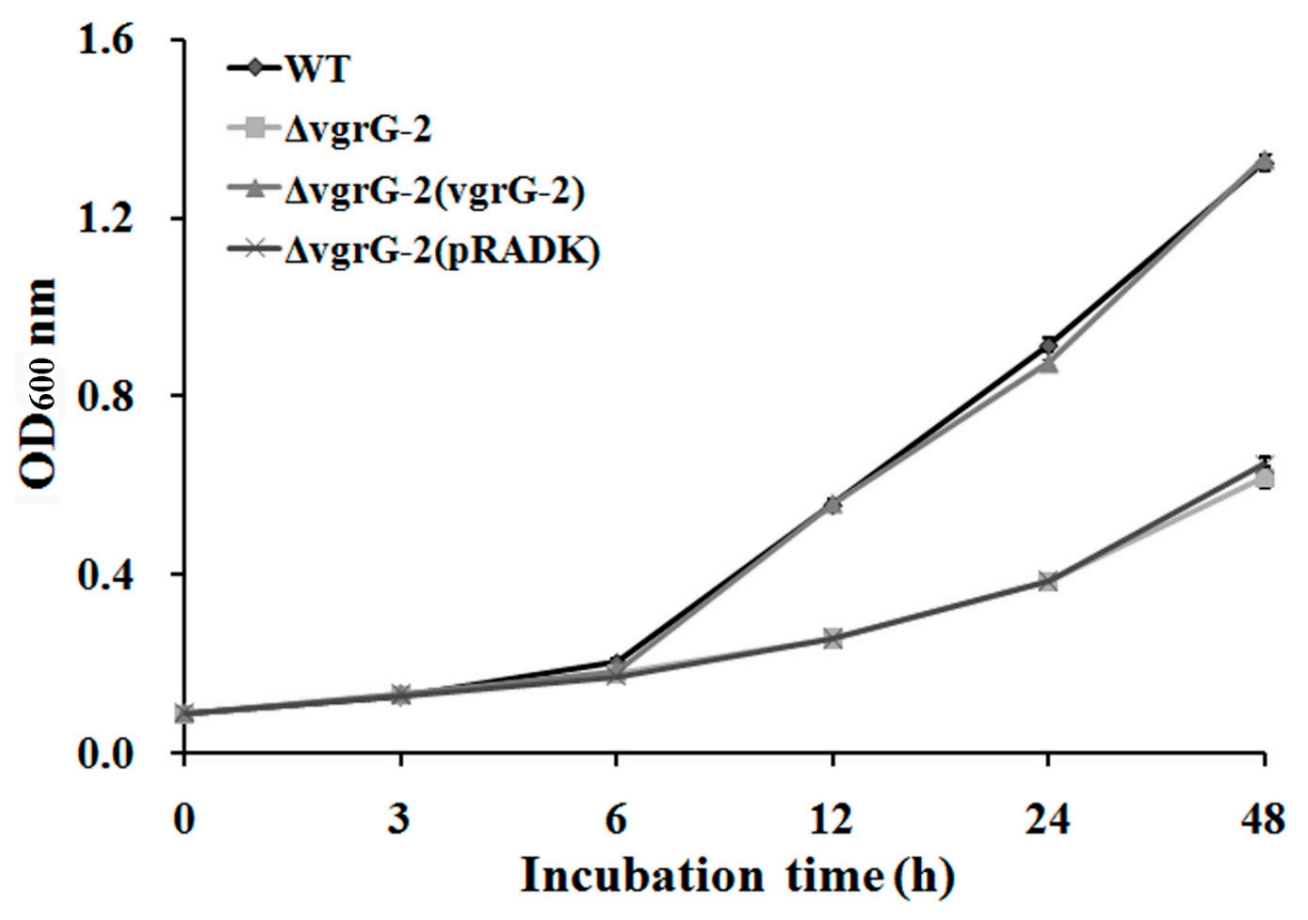

Figure 2. Comparison of growth between the wild type and $\Delta v g r G-2$ mutant of Acidovorax avenae subsp. avenae strain RS-1. WT: wild type strain; $\Delta v g r G-2: v g r G-2$ mutant strain; $\Delta v g r G$-2(vgrG-2): vgrG-2 complementary strain; $\Delta v g r G-2(\mathrm{pRADK})$ : mock strain with empty pRADK plasmid. Data from the repeated experiment were pooled and subjected to analysis of variance. Error bars represent the standard error of the mean.

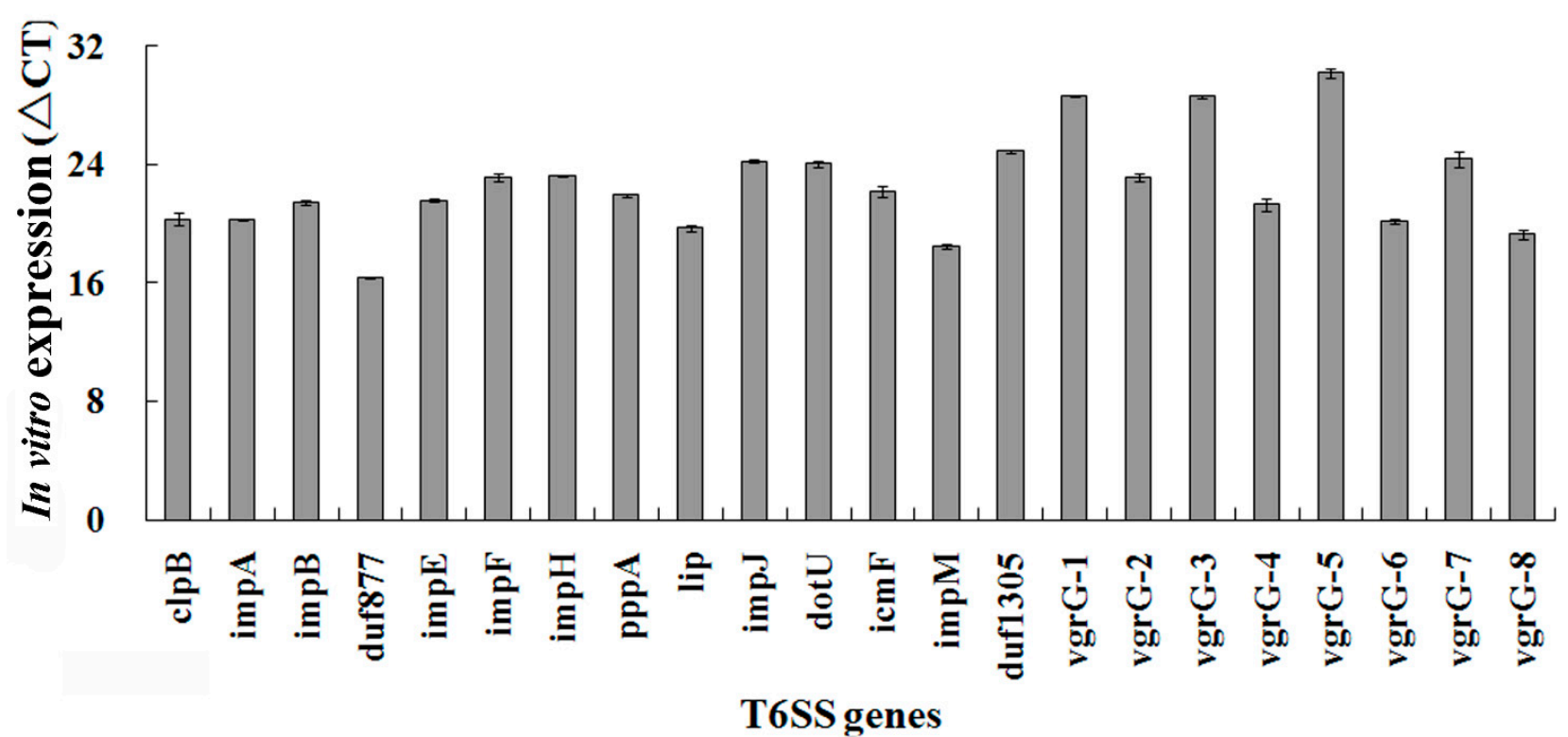

Figure 3. T6SS gene expression compared to 16S RNA gene, using quantitative real-time PCR in Acidovorax avenae subsp. avenae RS-1 under in vitro condition. 


\subsection{Different Expression of T6SS Gene under Various Environmental Conditions}

Differential changes were observed in T6SS gene expression of Aaa strain RS-1 during in vivo rice infection, co-culture with $B$. seminalis R456, and $v g r G-2$ mutation as well as high salt, low-temperature, $\mathrm{H}_{2} \mathrm{O}_{2}$ - and paraquat-mediated oxidative stress. The expression of $22 \mathrm{~T} 6 \mathrm{SS}$ genes was dependent on both the kind of gene and the type of condition (Table 1). Compared to the corresponding control, it was obvious that salt stress and low temperature up-regulated expression of most genes. On the contrary, the expression of most genes was down-regulated during in vivo infection and in $\mathrm{H}_{2} \mathrm{O}_{2}$ - and paraquat-induced oxidized stress. In addition, none of the 22 T6SS genes was up-regulated in the $\operatorname{vgr} G-2$ mutant.

Table 1. Gene expression of T6SS using quantitative real-time PCR in Acidovorax avenae subsp. avenae RS-1 during in vivo rice infection, $\operatorname{vgr} G-2$ mutant, and co-culture with rice rhizobacterium Burkholderia seminalis R456, as well as high salt, low temperature, $\mathrm{H}_{2} \mathrm{O}_{2}$ and paraquat-mediated oxidative stress.

\begin{tabular}{|c|c|c|c|c|c|c|c|}
\hline \multirow{2}{*}{$\begin{array}{l}\text { T6SS } \\
\text { Gene }\end{array}$} & \multicolumn{7}{|c|}{ Expression Change Relative to that of in Vitro under the Conditions of } \\
\hline & Salt ${ }^{a}$ & Temperature & Paraquat & $\mathrm{H}_{2} \mathrm{O}_{2}$ & Co-Culture & in Vivo & Mutant \\
\hline $\operatorname{clp} B$ & $\uparrow 1.3$ & $\uparrow 2.8 *$ & $\downarrow 14.8 *$ & $\downarrow 4.5 *$ & $\uparrow 15.0 *$ & $\downarrow 4.4 *$ & $\downarrow 1140.8 *$ \\
\hline impA & $\downarrow 12.3 *$ & $\uparrow 36.1 *$ & $\downarrow 5.1 *$ & $\downarrow 1.8$ & $\downarrow 1.8$ & $\downarrow 3.1 *$ & $\downarrow 14.1 *$ \\
\hline $\operatorname{imp} B$ & $\uparrow 20.9 *$ & $\uparrow 2.6 *$ & $\downarrow 1.1$ & $\uparrow 4.4 *$ & $\uparrow 7.4 *$ & $\uparrow 2.6 *$ & $\downarrow 27.0 *$ \\
\hline duf877 & $\downarrow 40.1 *$ & $\downarrow 1.5$ & $\downarrow 7.9 *$ & $\downarrow 10.2 *$ & $\uparrow 1.6$ & $\downarrow 2.2 *$ & $\downarrow 3008.4 *$ \\
\hline$i m p E$ & $\uparrow 2.0 *$ & $\uparrow 3.8 *$ & $\downarrow 4.5 *$ & $\downarrow 2.0 *$ & $\uparrow 1.4$ & $\uparrow 1.9$ & $\downarrow 28.8 *$ \\
\hline$i m p F$ & $\uparrow 23.2 *$ & $\uparrow 63.5 *$ & $\uparrow 9.5 *$ & $\uparrow 1.5$ & $\uparrow 3.4 *$ & $\uparrow 4.2 *$ & $\downarrow 11.8 *$ \\
\hline impH & $\uparrow 3.8 *$ & $\uparrow 1.2$ & $\downarrow 1.0$ & $\downarrow 2.7 *$ & $\downarrow 1.0$ & $\downarrow 1.3$ & $\downarrow 4.3 *$ \\
\hline pppA & $\uparrow 5.1 *$ & $\uparrow 2.7 *$ & $\downarrow 8.3 *$ & $\downarrow 1.7$ & $\uparrow 4.2 *$ & $\uparrow 1.8$ & $\downarrow 17.7 *$ \\
\hline lip & $\uparrow 5.7 *$ & $\downarrow 2.0 *$ & $\downarrow 5.9 *$ & $\downarrow 11.9 *$ & $\downarrow 5.7 *$ & $\downarrow 5.7 *$ & $\downarrow 31.6 *$ \\
\hline impJ & $\uparrow 51.2 *$ & $\uparrow 79.0$ * & $\downarrow 1.6$ & $\uparrow 2.9 *$ & $\uparrow 5.0 *$ & $\downarrow 1.4$ & $\downarrow 15.1 *$ \\
\hline $\operatorname{dot} U$ & $\downarrow 6.4 *$ & $\downarrow 16.9 *$ & $\downarrow 15.4 *$ & $\downarrow 37.6 *$ & $\downarrow 1.7$ & $\downarrow 10.9 *$ & $\downarrow 10.4 *$ \\
\hline$i c m F$ & $\uparrow 13.6^{*}$ & $\uparrow 2.4^{*}$ & $\uparrow 1.4$ & $\uparrow 1.1$ & $\uparrow 2.0 *$ & $\downarrow 1.9$ & $\downarrow 35.8 *$ \\
\hline impM & $\uparrow 2.4 *$ & $\uparrow 2.5^{*}$ & $\downarrow 6.2 *$ & $\downarrow 2.2 *$ & $\downarrow 2.7 *$ & $\downarrow 1.5$ & $\downarrow 400.6 *$ \\
\hline duf1305 & $\uparrow 39.5$ * & $\uparrow 115.5 *$ & $\downarrow 1.1$ & $\uparrow 2.0 *$ & $\uparrow 8.2 *$ & $\uparrow 2.5 *$ & $\downarrow 3.4 *$ \\
\hline $\operatorname{vgr} G-1$ & $\uparrow 1.0$ & $\downarrow 1.2$ & $\downarrow 1.4$ & $\downarrow 2.2 *$ & $\uparrow 1.7$ & $\uparrow 1.0$ & $\downarrow 1.8$ \\
\hline $\operatorname{vgr} G-2$ & $\uparrow 1.1$ & $\uparrow 1.7$ & $\downarrow 1.8$ & $\uparrow 1.1$ & $\uparrow 2.4 *$ & $\uparrow 2.4 *$ & $\downarrow 2.1 *$ \\
\hline $\operatorname{vgr} G-3$ & $\downarrow 4.0 *$ & $\uparrow 1.6$ & $\uparrow 3.0 *$ & $\downarrow 4.4 *$ & $\downarrow 2.1 *$ & $\downarrow 3.8 *$ & $\downarrow 2.5 *$ \\
\hline $\operatorname{vgr} G-4$ & $\uparrow 4.8 *$ & $\uparrow 17.1 *$ & $\uparrow 3.1 *$ & $\uparrow 1.7$ & $\uparrow 1.9$ & $\uparrow 1.7$ & $\downarrow 66.1 *$ \\
\hline $\operatorname{vgr} G-5$ & $\uparrow 20.6$ * & $\uparrow 597.0 *$ & $\uparrow 1028.9 *$ & $\uparrow 77.4^{*}$ & $\uparrow 20.1 *$ & $\uparrow 108.3 *$ & $\uparrow 123.9 *$ \\
\hline $\operatorname{vgr} G-6$ & $\uparrow 1.1$ & $\downarrow 1.8$ & $\downarrow 14.5 *$ & $\downarrow 7.0 *$ & $\downarrow 6.5 *$ & $\downarrow 2.2 *$ & $\downarrow 16.8 *$ \\
\hline $\operatorname{vgr} G-7$ & $\uparrow 1.6$ & $\downarrow 1.4$ & $\uparrow 2.8 *$ & $\downarrow 1.5$ & $\downarrow 3.6 *$ & $\uparrow 1.1$ & $\uparrow 1.1$ \\
\hline $\operatorname{vgr} G-8$ & $\downarrow 1.9$ & $\downarrow 4.0 *$ & $\downarrow 18.1 *$ & $\downarrow 9.4 *$ & $\downarrow 6.6 *$ & $\downarrow 3.5 *$ & $\downarrow 11.1 *$ \\
\hline
\end{tabular}

a Salt: $2 \% \mathrm{NaCl}$ high salt; Temperature: $15{ }^{\circ} \mathrm{C}$ low temperature; Co-culture: co-culture with rice rhizobacterium Burkholderia seminalis R456; Mutant: $\operatorname{vgrG}-2$ gene knockout mutant; $\mathrm{H}_{2} \mathrm{O}_{2}: 8 \mathrm{mM}$ $\mathrm{H}_{2} \mathrm{O}_{2}$-mediated oxidative stress; Paraquat: $50 \mu \mathrm{M}$ paraquat-mediated oxidative stress; In vivo: in vivo rice infection. $\uparrow$ : up-regulation; $\downarrow$ : down-regulation; *: the change of gene expression is more than two fold compared to the corresponding in vitro control. 
In this study, the transcript of almost all structural genes (except $\operatorname{dot} U$ ) and three $\operatorname{vgrGs}(v g r G-2$, $\operatorname{vgr} G-4, \operatorname{vgr} G-6)$ showed their maximum repression level of expression in response tovgrG-2 mutant. Five structural genes (impB, impH, pppA, liP and $i m c F)$ showed their maximum activation level of expression in response to in salt stress; six structural genes (impA, impE, impF, impJ, impM, duf1305) and one $\operatorname{vgr} G-4$ showed their maximum activation level of expression under low temperature stress. Based on the results, only one structural gene $\operatorname{clp} B$ and one $\operatorname{vgr} G-2$ showed the highest level of expression under co-culture condition; three $\operatorname{vgr} G \mathrm{~s}(\operatorname{vgr} G-3, \operatorname{vgr} G-5, \operatorname{vgr} G-7)$ showed their maximum activation level of expression under paraquat stress; and two $\operatorname{vgrGs}(\operatorname{vgrG}-1$ and $\operatorname{vgr} G-3)$ showed their maximum repression level of expression under $\mathrm{H}_{2} \mathrm{O}_{2}$ stress. Interestingly, no gene showed its special expression levels during in vivo infection (Table 1).

Salt stress caused differential expression of 16 genes (13 structural genes and three vgrGs), including 12 up-regulated genes and four down-regulated genes. Low temperature caused differential expression of 15 genes (12 structural genes and three $\operatorname{vgr} G \mathrm{~s}$ ), including 12 up-regulated genes and three down-regulated genes. $\mathrm{H}_{2} \mathrm{O}_{2}$ stress caused differential expression of 15 genes ( 10 structural genes and five $\operatorname{vgr} G \mathrm{~s}$ ), including four up-regulated genes and 11 down-regulated genes. In addition, Paraquat stress caused differential expression of 15 genes (nine structural genes and six $v g r G$ s), including five up-regulated genes and 10 down-regulated genes. Co-culture caused differential expression of 15 genes (nine structural genes and six $\operatorname{vgr} G \mathrm{~s}$ ), including nine up-regulated genes and six down-regulated genes. In vivo infection caused differential expression of 13 genes (eight structural genes and five $\operatorname{vgr} G \mathrm{~s}$ ), including five up-regulated genes and eight down-regulated genes. None of the 14 structural genes was significantly up-regulated in the $\operatorname{vgr} G-2$ mutant, but found to be down-regulated.

\subsection{Principle Component Analysis}

The relative expression (RE) levels of 22 T6SS genes under six stress conditions (no vgrG mutant condition) were subjected to principle component analysis (PCA). The data for gene expression in mutant condition was excluded from analyses because of the oversize (incalculable) change in the expression levels of several genes. The first and second principal components of PCA plot (PC1 and PC2) accounted for $37.6 \%$, and $24.5 \%$ of the variation, respectively, in the dataset (Figure 4 ). The contribution of conditions and genes as well as their interactions were determined based on the scores of PC1 and PC2. The relative importance of stress conditions and genes was determined based on their distance to the origin, the point where the two axes cross at zero on both scales. More distant (stress conditions and genes) from the origin was considered as more important factor for the expression levels.

The PCA results of condition factors in this study indicated that low temperature and high salt stresses were the most important contribution to the variation of RE levels, followed by $\mathrm{H}_{2} \mathrm{O}_{2}$, paraquat and co-culture stresses, while in vivo infection has the least contribution to the variation of RE levels based on their distance to the origin (Figure 4a). In addition, this study revealed three different types of contribution of stress types to the variation of RE levels. The different kinds of stress were grouped into three groups and significantly separated from left to right along the PC1 axis $(p<0.001)$ in order of group 1: (paraquat, $\mathrm{H}_{2} \mathrm{O}_{2}$, co-culture), group 2: (in vivo) and group 3: (temperature, salt).

Combining the PC1 axis and PC2 axis, the loadings of individual gene RE levels distributed on each quadrant indicated those genes are more related to these conditions that were on the same 
quadrant. The 22 T6SS genes were distributed in four quadrants by PC1 and PC2 axis. Some individual genes, like $p p p A, \operatorname{dot} U$ and $\operatorname{vgrG-5}$ were noted. $p p p A$ was close to PC2 axis, which indicated that $p p p A$ may be not only interact with paraquat and co-culture conditions but also with temperature condition. Furthermore, $\operatorname{dot} U$ and $\operatorname{vgr} G-5$ were close to origin, revealing that they may be able to, at least partially, interact with almost all conditions (Figure 4b). However, dot $U$ and $\operatorname{vgrG}-5$ have the least contribution to the RE levels based on the distance to the origin.
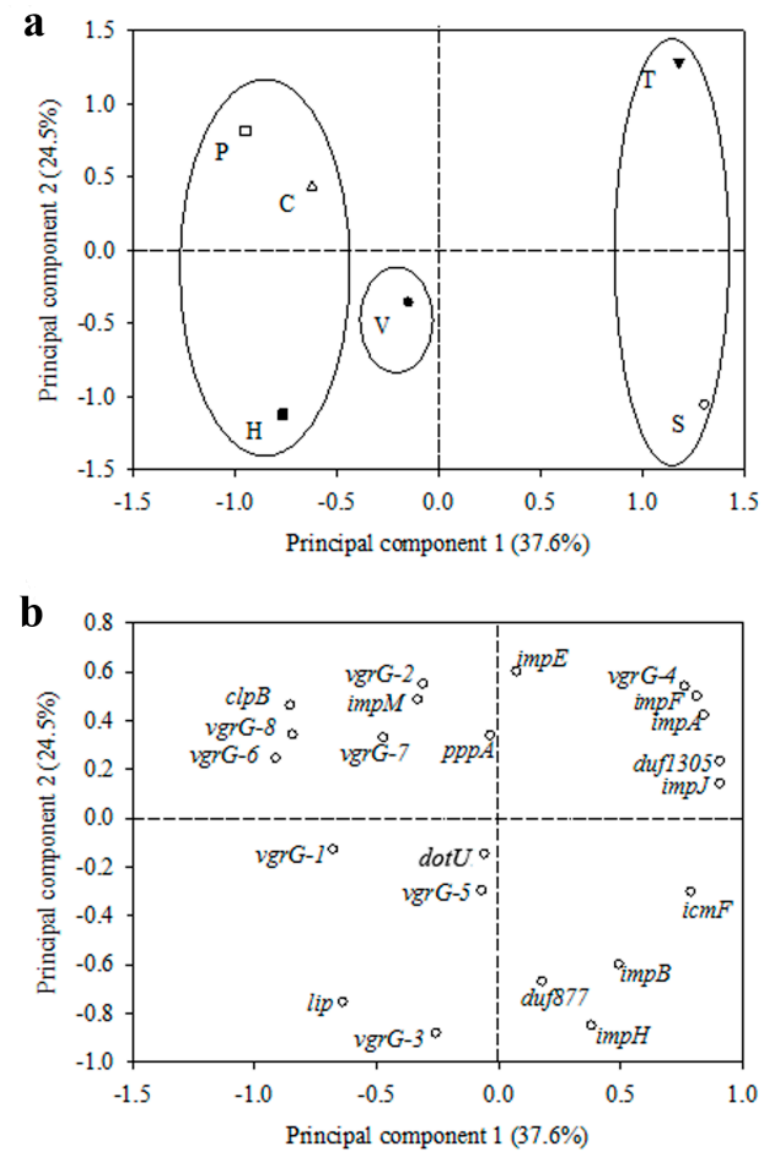

Figure 4. Two-dimensional principle component analyses (PCA) of 14 T6SS genes expression of Acidovorax avenae subsp. avenae RS-1 under 6 different conditions. (a) Scores from six different conditions; (b) loadings of the individual gene from the PCA of the relative expression data. S: $2 \% \mathrm{NaCl}$ high salt; $\mathrm{T}: 15{ }^{\circ} \mathrm{C}$ low temperature; $\mathrm{H}: 8 \mathrm{mM} \mathrm{H} \mathrm{O}_{2}$-mediated oxidative stress; P: $50 \mu \mathrm{M}$ paraquat-mediated oxidative stress; $\mathrm{C}$ : Co-culture with rice rhizobacterium Burkholderia seminalis $\mathrm{R} 456$; $\mathrm{V}$ : In vivo rice infection. The $\operatorname{vgr} G-2$ mutation was excluded in PCA for the oversize change in several T6SS genes expressions. The different kinds of conditions were grouped into two groups and significantly separated from left to right along the PC1 axis in the order of (paraquat, $\mathrm{H}_{2} \mathrm{O}_{2}$, co-culture), (in vivo) and (temperature, salt) $(p<0.001)$.

\section{Discussion}

Bacterial pathogens are often exposed to various kinds of environmental stresses during host infection. Furthermore, a particular bacterial species is likely to encounter numerous taxonomically-different 
competitors in host and natural ecosystems [32]. Therefore, the molecular survival mechanism of bacteria is mainly dependent on their adaptation to the different hosts and environmental conditions. Identification of specific genes and gene expression patterns is important for studying the host infection and natural environmental survival of a bacterial pathogen. Recently, a review of T6SS indicated that T6SS may play key roles in microbial communities leading to more contributions to microbial interactions for environmental benefits [33]. Although T6SS is involved in a series of bacterial process, no research has been carried out to assess the effect of T6SS and its expression to host infection and environmental stresses. On the other hand, VgrGs, as one of the two putative effectors of T6SSs, are considered to play an important role in the function of T6SS machine [34-37]. Therefore, ecological roles of T6SS in Aaa RS-1 could be, at least in part, determined by understanding the effect of host infection, natural environmental stresses and gene mutation on the expression pattern of T6SS structural genes and $\operatorname{vgr} G$ s.

In agreement with previous research, this study revealed that bacteria adapt to different conditions such as low temperature, osmotic, and oxidative-induced stresses by changing the growth rate. It is known that bacteria are often subject to these stresses in the natural environment $[19,38,39]$. However, the extent of the changes depends on the type of conditions. T6SS was also found to be able to response to a variety of environmental conditions. In this study, four common environmental stress conditions were chosen to get the stress repression point for the growth of Aaa RS-1 during in vivo infection, co-culture with $B$. seminalis R456 (a rice rhizobacterium) and $v g r G-2$ mutation, to evaluate the efficacy of T6SS gene expression in adaptation to these seven stress conditions. Although a broad set of differentially-expressed genes have been observed in the response of bacteria to osmotic stress $[25,40]$, no research was found about the role of T6SS in bacterial response to the salt stress. However, in this study, the result of PCA indicated that salt stress was one of the most important stress effectors interacted with T6SS gene expression. Four T6SS structure genes including $i c m F, i m p B$, impH, and $d u f 877$ were tightly interacted with salt-induced osmotic stress in PCA suggesting that the formation of T6SS structure may be related with the response of Aaa RS-1 to salt stress. Furthermore, little information is available about the role of VgrGs in bacterial response to environmental stresses. In this study, it became clear that the expression of most $\operatorname{vgr} G$ s (except $v g r G-4$ ) is affected by paraquat stress, $\mathrm{H}_{2} \mathrm{O}_{2}$ stress, and co-culture condition. However, the expression level of some vgrGs was not equal in paraquat stress and co-culture conditions, which suggest that multiple VgrGs in Aaa RS-1 maybe not be the result of a duplication but rather a gain of specific function, such as complementary expression in stress conditions. Although paraquat and $\mathrm{H}_{2} \mathrm{O}_{2}$ have a similar induced-oxidase mechanism, they were placed in the same group, but different spatial compartment, of PCA, indicating the complexity of the interaction between T6SS especially VgrGs with paraquat and $\mathrm{H}_{2} \mathrm{O}_{2}$.

T6SS has been experimentally shown to play a role in virulence in many cases. It may have an effect on limiting bacterial replication or virulence, increasing interaction with hosts other than pathogenesis which can lead to commensal or mutualistic conditions [41]. In some cases, putative T6SS components contribute to virulence, but in a manner that appears to be independent of other T6SS components [41]. Furthermore, expression of T6SS gene has been initially discovered as being specifically induced in vivo in many animal and human pathogens [42,43]. In this study, in vivo expressions of more than $50 \%$ of T6SS genes (13 of 22) were significantly changed, which showed that the T6SS genes were involved in the interaction between Aaa RS-1 and host. However, in contrast 
with the up-regulation in other animal and human pathogens $[42,43]$, expression of most genes was down-regulated among 13 genes in Aaa RS-1, suggesting the complexity of T6SS expression in plant pathogenic bacteria. On the other hand, the transcriptomic level of gene expression may be not always having a positive correlation with translation level of protein. Several studies also revealed that T6SS, in most cases, are not critical factors of pathogenesis, but rather improve the efficiency of colonization and/or infection of bacterial pathogens by attacking or killing the other bacteria [44]. Similar to the result of previous studies [44], this study also revealed that the expression of 15 genes was altered in Aaa RS-1 when confronted with rice rhizospheric bacterium B. Seminalis. It may indicate that T6SSs can, at least in part, contribute to the interaction of Aaa RS-1 with other bacteria.

The result of PCA indicated that two genes including $\operatorname{dot} U$ and $\operatorname{vgr} G-5$ were very close but near to the origin point. This suggests that the two genes may be able to interact with all conditions such as in vivo infection condition. Interestingly, the in vivo expression change of $\operatorname{dot} U(\mathrm{OmpA} / \mathrm{MotB})$ was more than 10-fold compared to the control (in vitro), suggesting that $\operatorname{dot} U$ has stronger response to host infection than other T6SS genes. Furthermore, in agreement with Broms et al. (2012) [37], the role of $\operatorname{dot} U$ in the virulence of Aaa RS-1 was justified by the fact that its mutant lost or significantly reduced virulence to rice plants (data not shown). In addition, our previous study revealed that OmpA/MotB domain containing proteins was in vivo expressed in Aaa RS-1 [32], while the interaction between DotU and IcmF has also been identified in Aaa RS-1 (data not shown). In this study, there was an indirect correlation between the expressions level of $\operatorname{dot} U$ and $i c m F$ in all six conditions of qPCR, indicating the negative-interaction between them.

PCA revealed a slight effect of $v g r G-5$ as it was close to the origin point. However, the expression of $\operatorname{vgrG-5}$ was significantly changed in all conditions. The contrast result may be due to this fact that qPCR revealed differences in expression of T6SS gene under the same condition or one T6SS gene under seven conditions. In addition to $\operatorname{vgr} G-5$, study of the other VgrG-coding genes is a good area of research because they encode the most important putative T6SS effectors. In this study, eight $\operatorname{vgrGs}$ which have high homology to each other in Aaa RS-1 were picked up for examination of gene expression. The result showed that the $\operatorname{vgr} G$ s were more sensitive to the stress group of (paraquat, $\mathrm{H}_{2} \mathrm{O}_{2}$, co-culture) than the stress group of (temperature, salt).

This study revealed the considerable changes of T6SS gene expression in Aaa RS-1 under in vivo infection, co-culture with rhizobacterium, and $\operatorname{vgr} G-2$ mutant as well as high salt, low-temperature, $\mathrm{H}_{2} \mathrm{O}_{2}$ - and paraquat-induced oxidative stresses. The extent of the changes depended on the type of conditions. The expression of the T6SS gene under these stress conditions was analyzed by qPCR. As a first study, PCA was used in exploring the potential interaction between T6SS gene expression and stress conditions. In general, the result of qPCR and PCA showed that high salt and low temperature had a higher impact on expression of T6SS structural genes whereas expression of $v g r G \mathrm{~s}$ was more sensitive to $\mathrm{H}_{2} \mathrm{O}_{2}$ - and paraquat-induced oxidative stresses. Expression of almost all T6SS structural genes was highly repressed in $\operatorname{vgr} G-2$ mutant. Therefore, this study might provide a clue for further studies about the role of T6SS in the response of Aaa RS-1 to host infection, taxonomically different competitors, gene mutation, and various kinds of environmental stresses. 


\section{Experimental Section}

\subsection{Bacterial Strains, Plasmids and Chemicals}

Bacteria and plasmids used in this study are listed in Table 2. Aaa RS-1 and B. seminalis R456 were isolated from diseased rice plants [45] and rice rhizosphere [46], respectively. Bacteria were stored in $20 \%-30 \%$ sterile glycerol (Shanglin Industries, Hangzhou, China) at $-80{ }^{\circ} \mathrm{C}$. Sodium chloride $(\mathrm{NaCl})$ was obtained from Shisihewei Chemical Reagent Co., Ltd. (Shanghai, China), $\mathrm{H}_{2} \mathrm{O}_{2}$ was obtained from Sinopharm Chemical Reagent Co., Ltd. (Shanghai, China), and paraquat (paraquat dichloride X-hydrate) was purchased from Sigma-Aldrich (St. Louis, MO, USA). Bacterial strains were regularly cultured and maintained at initial concentration of $10^{5} \mathrm{CFU} / \mathrm{mL}$ in $\mathrm{NB}$ (peptone $10.0 \mathrm{~g} / \mathrm{mL}$, yeast extract $3.0 \mathrm{~g} / \mathrm{mL}, \mathrm{NaCl} 5.0 \mathrm{~g} / \mathrm{mL}, \mathrm{pH} 7.5$ ) at $30{ }^{\circ} \mathrm{C}, 200 \mathrm{rpm}$ for $24 \mathrm{~h}$, unless specifically described.

Table 2. Strains and plasmids used in this study.

\begin{tabular}{|c|c|c|}
\hline Strain or Plasmid & Description & Source or Reference \\
\hline \multicolumn{3}{|c|}{ Strains } \\
\hline \multicolumn{3}{|c|}{ Acidovorax avenae subsp. avenae } \\
\hline RS-1 & $\begin{array}{l}\text { The pathogen of bacterial brown stripe of rice, isolated } \\
\text { from the diseased rice from Zhejiang province in China. } \\
\text { Wild type strain in this study }\end{array}$ & Lab collection \\
\hline$\Delta v g r G-2$ & $\mathrm{Km}^{\mathrm{R}}$; RS-1 in-frame deletion mutation defective in vgrG-2 & This study \\
\hline$\Delta v g r G-2(\operatorname{vgrG}-2)$ & $\begin{array}{c}\mathrm{Km}^{\mathrm{R}} ; \mathrm{Chl}^{\mathrm{R}} ; \text { complementary strain of } \Delta v g r G-2 \\
\text { complemented with pRADK-vgrG2 }\end{array}$ & This study \\
\hline$\Delta v g r G-2(\mathrm{pRADK})$ & $\mathrm{Km}^{\mathrm{R}} ; \mathrm{Chl}^{\mathrm{R}}$; mock strain of $\Delta v g r G-2$ with empty pRADK & This study \\
\hline $\begin{array}{c}\text { Burkholderia } \\
\text { seminalis } \mathrm{R} 456\end{array}$ & $\begin{array}{l}\text { Isolated from rice rhizosphere from Zhejiang province in } \\
\text { China. Biocontrol bacterium used in this study }\end{array}$ & Lab collection \\
\hline $\begin{array}{l}\text { Escherichia coli } \\
\quad \text { S17-1 } \lambda \text { pir }\end{array}$ & $\begin{array}{l}\lambda \text { Lysogenic S17-1 derivative producing } \pi \text { protein for } \\
\text { replication of plasmids carrying R6Kori; } \\
\text { recAprohsdRRP4-2-Tc::Mu-Km::Tn7 } \lambda^{-} \text {pir }\end{array}$ & Liu et al. (2012) [47] \\
\hline \multicolumn{3}{|c|}{ Plasmids } \\
\hline pJP5603 & Suicide vector; R6Kori, $\mathrm{Km}^{\mathrm{R}}$ & Liu et al. (2012) [47] \\
\hline pJP-G & $\begin{array}{c}\mathrm{Km}^{\mathrm{R}} \text {; pJP5603 containing the } 440 \text { bp DNA fragment } \\
\text { of gene } v g r G \text {-2 from Strain RS-1; used to create } \\
\text { mutant } \Delta v g r G-2\end{array}$ & This study \\
\hline pRADK & $\mathrm{Chl}^{\mathrm{R}}$; broad host expression vector & Liu et al. (2012) [47] \\
\hline pRADK-vgrG2 & $\begin{array}{l}\mathrm{Chl}^{\mathrm{R}} \text {; pRADK plasmid containing the } \operatorname{vgr} G-2 \\
\text { gene and upstream fragment from strain RS-1, } \\
\text { utilize to complement }\end{array}$ & This study \\
\hline
\end{tabular}

$\mathrm{Km}^{\mathrm{R}}, \mathrm{Chl}^{\mathrm{R}}$ : Kanamycin- and Chloromycetin-resistant, respectively.

\subsection{Bacterial Growth in High Salt, Low Temperature and Oxidative Stress Conditions}

In order to find the appropriate stress repression point for Aaa RS-1, the growth of the bacteria was firstly determined in different stress conditions of different concentrations. Bacterial adaptation to different environments was determined by examining cell growth in high salt, low temperature, and 
oxidative stress conditions. The 96-well microplates (Corning-Costar Corp., Corning, NY, USA) were used for this purpose. For salt stress treatment, each well in the 96-well microplates was inoculated with $200 \mu \mathrm{L}$ of bacterial suspension $\left(\mathrm{OD}_{600}=0.1\right.$ ) with $\mathrm{NaCl}$ concentrations of $1.0 \%$ (Optimum concentration, served as the control), $2.0 \%, 3.0 \%, 4.0 \%, 5.0 \%, 6.0 \%, 7.0 \%, 8.0 \%$, and $9.0 \%$. For low temperature treatment, bacterial growth was determined after incubating $200 \mu \mathrm{L}$ of bacterial suspension $\left(\mathrm{OD}_{600}=0.1\right)$ at 15 and $30^{\circ} \mathrm{C}$ (Optimum temperature, served as the control) for $0,3,6,12$ and $24 \mathrm{~h}$, respectively. For $\mathrm{H}_{2} \mathrm{O}_{2}$ treatment, bacterial suspension was incubated with 0.0 (the control), 8.0, 16.0, and $32.0 \mathrm{mM}$ of $\mathrm{H}_{2} \mathrm{O}_{2}$ at $30{ }^{\circ} \mathrm{C}$ for $24 \mathrm{~h}$. The effect of paraquat on bacterial growth was determined by incubating the bacterial suspension $\left(\mathrm{OD}_{600}=0.3\right)$ with 0.0 (the control), 10.0, 50.0, and $100.0 \mu \mathrm{M}$ of paraquat, at $30{ }^{\circ} \mathrm{C}$ for $0,8,16$, and $24 \mathrm{~h}$, respectively. The $\mathrm{NB}$ without bacteria was used as the negative control for this experiment. Finally, the $\mathrm{OD}_{600}$ of each plate was determined and bacterial growth was evaluated based on the $\mathrm{OD}_{600}$ of six biological replicates.

\subsection{Bacterial Growth in Co-Culture and in Vivo Planta Conditions}

The effect of co-culture on T6SS gene expression was examined by incubating Aaa RS-1 either alone or in combination with B. seminalis R456 according to Ruiz et al. (2009) [48]. Briefly, both bacterial strains were incubated in $40 \mathrm{~mL}$ of NB for overnight at $30^{\circ} \mathrm{C}$. In order to allow the interchange of secreted molecules present in the supernatants, the content of each tube was drawn in a sterile syringe and a sterile filter of $32 \mathrm{~mm}$ diameter and $0.45 \mu \mathrm{m}$ pore size (Pall-Newquay) was connected to each syringe. Both syringe-filter sets, each one containing one bacterial strain, were interconnected by means of single and sterile fused-silica tubing, and the media of both syringes were manually mixed every $2 \mathrm{~h}$. Batch cultures for each strain were performed at the same time and the whole procedure was independently repeated at least twice.

The bacterial growth during in vivo rice infection was determined by collecting bacteria from diseased rice leaves directly as described in our previous study [32]. Briefly, bacterial strain was inoculated and recovered as follows. Leaves of four-week-old plants were infiltrated with sterilized syringe filled with $10 \mathrm{~mL}\left(\sim 10^{8} \mathrm{CFU} / \mathrm{mL}\right)$ of bacterial suspension. Six days after the inoculation, infected leaves were collected and decontaminated with alcohol. Leaves were cut into pieces with a sterile razor blade and maintained for $1 \mathrm{~h}$ in sterile glass plates containing $20 \mathrm{~mL}$ of distilled water. The incubation during this period of time allowed the bacteria to detach from the leaf tissues. The leaves were separated from the suspension and the bacterial cells were collected by centrifugation at 5000 RCF for $20 \mathrm{~min}$. The bacterial cell pellets were then washed with phosphate buffer saline (PBS) and with water and then used for RNA extraction.

\subsection{Construction of vgrG-2 Mutant and Complementation}

The effect of gene mutation on bacterial growth and T6SS gene expression was determined by constructing one $\operatorname{vgr} G$ mutant of Aaa RS-1. In-frame deletion of $\operatorname{vgrG}$-2 gene and complementation were performed as described of Liu et al. (2012) [47] by suicide plasmid pJP5603 through homologous recombination on the background of wild-type strain RS-1. For construction of the $v g r G-2$ deletion strain, $205 \mathrm{bp}$ internal DNA fragment of $v g r G-2$ was PCR amplified with primers designed according to Aaa RS-1 genome. The PCR product was cloned into pMD19-T vector (TaKaRa, Dalian, China), 
verified by sequencing and digestion with BamHI and EcoRI, and then ligated into the suicide vector pJP5603 to get pJp-G. For transfer of plasmid, the E. coli S17-1 $\lambda$ pir has been employed and the resulting plasmid was then introduced into Aaa RS-1 via electroporation. This $\operatorname{vgrG-2}$ gene may be targeted during transcription because of the high similarity between the internal fragments harbored by suicide plasmid and genomic DNA. The homologous recombination mutants were obtained after a single integrative recombination event, which disconnected essential protein domains, resulting in truncated and non-functional VgrG-2 protein. Mutant checking of the $\operatorname{vgrG-2}$ among eight $\operatorname{vgrGs}$ of high sequence similarity were further confirmed by examining the expression of either side of the part knocked out using qPCR. In order to complement the $\Delta v g r G-2$ strain, $v g r G-2$ open reading frame was amplified from the wide strain, along with $300 \mathrm{bp}$ upstream of its start codon so that it included its native promoter. The 2652 bp PCR product was cloned into pGEM-T Easy vector, verified by sequencing, and then cloned into pRADK. The complementation vector was introduced into mutant cells by filter mating and selected by $\mathrm{Chl}+\mathrm{Km}$ resistance. In addition, mock strain was constructed by introducing empty pRADK into mutant cells. The primers were listed in Table 3.

Table 3. Primers of T6SS genes used for quantitative real-time PCR (qPCR) of Acidovorax avenae subsp. avenae RS-1 in this study.

\begin{tabular}{|c|c|c|c|}
\hline $\begin{array}{l}\text { T6SS } \\
\text { Gene }\end{array}$ & Primer Sequence $\left(5^{\prime} \rightarrow 3^{\prime}\right)$ & Target PCR Product of Function & $\begin{array}{c}\text { Amplication } \\
\text { Size (bp) }\end{array}$ \\
\hline $\operatorname{clp} B$ & $\begin{array}{l}\text { F-GCAGGGCGAGAAGGACAAG } \\
\text { R-GCCGAGGAACAGGAACGAG }\end{array}$ & ATP-dependent chaperone ClpB & 159 \\
\hline $\operatorname{imp} A$ & $\begin{array}{l}\text { F-CTTGAACCTGCGGCGGACAC } \\
\text { R-GCTCGGCGGGAATCACCAT }\end{array}$ & $\begin{array}{l}\text { Type VI secretion-associated protein, } \\
\text { ImpA family }\end{array}$ & 129 \\
\hline$i m p B$ & $\begin{array}{l}\text { F-ATCTCCСТCATCCTGCTCA } \\
\text { R-TCAGATGCGTCCCATCAG }\end{array}$ & Hypothetical protein Aave_2851 & 152 \\
\hline duf877 & $\begin{array}{l}\text { F-GCACCACCTGGTCCACAACA } \\
\text { R-CGAACTGGCCGTATTCCTCT }\end{array}$ & Type VI secretion protein EvpB & 163 \\
\hline impE & $\begin{array}{c}\text { F-TGATCGGCTCGCTGTTCG } \\
\text { R-TGCTTGTACTCGCCCTTGTT }\end{array}$ & Guanosine monophosphate reductase & 120 \\
\hline$i m p F$ & $\begin{array}{l}\text { F-TGGACTGGAAGGACGTGGAA } \\
\text { R-AGGGTGTTGTGGTGGTTGAA }\end{array}$ & $\begin{array}{c}\text { Type VI secretion system } \\
\text { lysozyme-like protein }\end{array}$ & 126 \\
\hline impH & $\begin{array}{l}\text { F-TGGAACTTCGGCCTCTATGG } \\
\text { R-TGGTGGAAGATGTCCGAGAA }\end{array}$ & Type VI secretion protein & 121 \\
\hline рррА & $\begin{array}{l}\text { F-AGATCACGCGGGACCATT } \\
\text { R-TTCCTCGTCGTCGAGCAT }\end{array}$ & Protein serine/threonine phosphatase & 214 \\
\hline lip & $\begin{array}{c}\text { F-GCAGTGCGGATGTCCGTACCTT } \\
\text { R-TCCTTGCCCACCGTGATGCT }\end{array}$ & Type VI secretion lipoprotein & 174 \\
\hline impJ & $\begin{array}{l}\text { F-TCCAGGATGCCAACGACA } \\
\text { R-GACCACGGTGGGAATGAA }\end{array}$ & Type VI secretion protein, VC_A0114 family & 181 \\
\hline $\operatorname{dot} U$ & $\begin{array}{l}\text { F-CCAGCATTACCTGCTCGAAT } \\
\text { R-CCAGGTCTCGTTGTGCAGT }\end{array}$ & $\begin{array}{c}\text { DotU family type IV/VI secretion } \\
\text { system protein }\end{array}$ & 196 \\
\hline$i c m F$ & $\begin{array}{l}\text { F-ACCGTGGGCAGCAATCTCA } \\
\text { R-GCGAAGTCATCGCTCGTCA }\end{array}$ & Type VI secretion protein IcmF & 112 \\
\hline
\end{tabular}


Table 3. Cont.

\begin{tabular}{|c|c|c|c|}
\hline $\begin{array}{l}\text { T6SS } \\
\text { Gene }\end{array}$ & Primer Sequence $\left(5^{\prime} \rightarrow 3^{\prime}\right)$ & Target PCR Product of Function & $\begin{array}{c}\text { Amplication } \\
\text { Size (bp) }\end{array}$ \\
\hline impM & $\begin{array}{l}\text { F-GCAATGGCGTCGTCCTCT } \\
\text { R-CGGTCGTGCCGATCTTCT }\end{array}$ & Adenylosuccinate synthase & 192 \\
\hline dufl 1305 & $\begin{array}{l}\text { F-GCCACAAGTTCCTTTTGCA } \\
\text { R-AAGAACGGCACGAAATCC }\end{array}$ & Type VI secretion protein,VC_A0111 family & 202 \\
\hline $\operatorname{vgr} G-1$ & $\begin{array}{l}\text { F-ATCCGATGGAAAAGAAACTC } \\
\text { R-AATAGATGCCCTCGTGCT }\end{array}$ & Rhs element Vgr protein Aave_0481 & 113 \\
\hline $\operatorname{vgr} G-2$ & $\begin{array}{l}\text { F-GCGTGCAATATGACGAGAGC } \\
\text { R-CCGGCGGATAGAAGGGAATC }\end{array}$ & Rhs element Vgr protein Aave_0497 & 174 \\
\hline $\operatorname{vgr} G-3$ & $\begin{array}{c}\text { F-CGCACGATGCCTACGAGAT } \\
\text { R-TTCGCCTTTGACGACGCT }\end{array}$ & Rhs element Vgr protein Aave_2047 & 121 \\
\hline $\operatorname{vgr} G-4$ & $\begin{array}{l}\text { F-CTGACGCAGAGCACGAAT } \\
\text { R-CCGAAGCACCACATACCA }\end{array}$ & Rhs element Vgr protein Aave_2127 & 150 \\
\hline $\operatorname{vgr} G-5$ & $\begin{array}{l}\text { F-CATCAAGACCAAGTCCAGC } \\
\text { R-CAGCCATAATTGCTCTGC }\end{array}$ & Rhs element Vgr protein Aave_2735 & 114 \\
\hline $\operatorname{vgr} G-6$ & $\begin{array}{l}\text { F-ATACTGCGTGCAATATGACG } \\
\text { R-GATTTCTCGGGCGGATAG }\end{array}$ & Rhs element Vgr protein Aave_2840 & 185 \\
\hline $\operatorname{vgr} G-7$ & $\begin{array}{l}\text { F-CCGATGGAAAAGAAACTCAG } \\
\text { R-AATAGATGCCCTCGTGCT }\end{array}$ & Rhs element Vgr protein Aave_3347 & 111 \\
\hline $\operatorname{vgr} G-8$ & $\begin{array}{l}\text { F-TCCTTCCAGAAGTTCAGCC } \\
\text { R-GGTATTCGTCGGTCCAGATT }\end{array}$ & Rhs element Vgr protein Aave_0241 & 144 \\
\hline vgrG-2s & $\begin{array}{l}\text { F-TACCCGCCCGAGAAGT } \\
\text { R-CCGGCCATTCGTAGATC }\end{array}$ & $\begin{array}{l}\text { Forepart fragment of the knockout } \\
\text { fragment in } \operatorname{vgr} G-2\end{array}$ & 169 \\
\hline vgrG-2b & $\begin{array}{l}\text { F-ACGGGTGTCTTCAAGATGG } \\
\text { R-TGAGGGTGATGCTGGTTT }\end{array}$ & $\begin{array}{l}\text { Tail fragment of the knockout fragment } \\
\text { in } v g r G-2\end{array}$ & 197 \\
\hline CvgrG-2 & $\begin{array}{l}\text { F-ACACCACTTCGACGAGGTGCTG } \\
\text { R-TCAGTTCAGGTGGATGTCTTCGC }\end{array}$ & $\begin{array}{l}\operatorname{vgr} G-2 \text { open reading frame with its } \\
\text { promoter region }\end{array}$ & 2652 \\
\hline 16s RNA & $\begin{array}{c}\text { F-TTGCGGTCCCCTGCTTTCAT } \\
\text { R-CGGTAACAGGTCTTCGGATGCT }\end{array}$ & Reference gene used for qPCR in this study & 120 \\
\hline
\end{tabular}

\subsection{RNA Extraction and Gene Expression Analysis Using Quantitative Real-Time PCR}

This experiment was conducted to assess the expression pattern of T6SS gene in Aaa RS-1 cells subjected to different stress treatments including: incubation in $\mathrm{NB}$ with $2.0 \%$ of $\mathrm{NaCl}$ for high salt stress, incubation at $15{ }^{\circ} \mathrm{C}$ for low temperature stress, incubation in $\mathrm{NB}$ with $8.0 \mathrm{mM}$ of $\mathrm{H}_{2} \mathrm{O}_{2}$ and incubation in NB with $50.0 \mu \mathrm{M}$ of paraquat for oxidative stresses, co-culture with B. seminalis R456 and finally inoculated and recovered from the host plant. Bacteria incubated in $\mathrm{NB}$ with $1.0 \%$ of $\mathrm{NaCl}$ at $30{ }^{\circ} \mathrm{C}$ were used as the control. All the in vitro treatments were cultured for $24 \mathrm{~h}$. Total RNAs from each sample was extracted by using high pure RNA isolation kit (Roche, Hangzhou, China) according to the manufactory instructions. RNA was treated with DNase I and reverse-transcribed into cDNA using a Prime Script ${ }^{\mathrm{TM}}$ RT reagent Kit with gDNA Eraser (TaKaRa, Dalian, China). The resulting cDNAs were used as the template for expression detection analysis of the T6SS gene with qPCR using a SYBR $^{\circledR}$ Premix Ex Taq ${ }^{\mathrm{TM}}$ (TaKaRa, Dalian, China) following the instruction of kit manual on an ABI 
Prism 7500 sequence detection system (Applied Biosystems, Foster City, CA, USA). The gene-specific primer sequences are shown in Table 3. The average threshold cycle $\left(C_{\mathrm{t}}\right)$ was used to determine the fold change of gene expression. In addition, 16S rRNA gene was used as an internal control. The $2^{-\Delta \Delta C t}$ method was used for relative quantification [49]. Each result represents the average of three independent determinations. This experiment was repeated twice.

\subsection{Principle Component Analysis of Gene Expression}

The PCA method was used for the data of T6SS gene expression under different conditions. The RE was subjected to PCA after standardizing to unit variance. Resulting factor scores of the PC1 and PC2 were tested in two-way analysis of variances (ANOVA). Data analyses were carried out using the SPSS 16.0 software (SPSS, Michigan Avenue, Chicago, IL, USA). The figures were produced by using the SigmaPlot 10.0 software (SYSTAT Software, Inc., San Jose, CA, USA).

\subsection{Statistics Analysis}

The software STATGRAPHICS Plus, version 4.0 (Copyright Manugistics Inc., Rockville, MD, USA) was used to perform the statistical analysis. Levels of significance $(p<0.05)$ of main treatments and their interactions were calculated by analysis of variance after testing for normality and variance homogeneity.

\section{Acknowledgments}

This work was supported by National Natural Science Foundation of China (31371904), Zhejiang Provincial Natural Science Foundation of China (R13C140001), Zhejiang Provincial Project (2014C32010), Shanghai Agricultural Basic Research Project (2014:2-7), the Fundamental Research Funds for the Central Universities, the Agricultural Ministry of China (nyhyzx 201303015) and Key Subject Construction Program of Zhejiang for Modern Agricultural Biotechnology and Crop Disease Control (2010DS700124-KF1101; 2010DS700124-KF1203; 2010DS700124-KF1309; 2010DS700124-KF1410).

\section{Author Contributions}

Zhouqi Cui: designed methods and experiments, analyzed the data, and interpreted the results and wrote the manuscript. Guoqiang Jin: coordinated the project and provided financial support. Kaleem Ullah Kakar: carried out the laboratory experiments, analyzed array data and manuscript writing. Yangli Wang: coordinated the project and provided financial support. Guanlin Xie: coordinated the project and provided financial support. Guochang Sun: coordinated the project and provided financial support. Mohammad Reza Ojaghian: helped with some laboratory works and writing the manuscript. Bin Li: conceived of the study, designed methods and experiments, wrote the manuscript, had final approval and takes responsibility for the manuscript.

\section{Conflicts of Interest}

The authors declare no conflict of interest. 


\section{References}

1. Pukatzki, S.; Ma, A.T.; Revel, A.T.; Sturtevant, D.; Mekalanos, J.J. Type VI secretion system translocates a phage tail spike-like protein into target cells where it cross-links actin. Proc. Natl. Acad. Sci. USA 2007, 104, 15508-15513.

2. Cossart, P. Bacterial invasion: A new strategy to dominate cytoskeleton plasticity. Dev. Cell 2004, 6, 314-315.

3. Mota, L.J.; Cornelis, G.R. The bacterial injection kit: Type III secretion systems. Ann. Med. 2005, 37, 234-249.

4. Gerlach, R.G.; Hensel, M. Protein secretion systems and adhesins: The molecular armory of Gram-negative pathogens. Int. J. Med. Microbiol. 2007, 297, 401-415.

5. Johnson, T.L.; Abendroth, J.; Hol, W.G.J.; Sandkvist, M. Type II secretion: From structure to function. FEMS Microbiol. Lett. 2006, 255, 175-186.

6. Pukatzki, S.; Ma, A.T.; Sturtevant, D.; Krastins, B.; Sarracino, D.; Nelson, W.C.; Heidelberg, J.F.; Mekalanos, J.J. Identification of a conserved bacterial protein secretion system in Vibrio cholerae using the Dictyostelium host model system. Proc. Natl. Acad. Sci. USA 2006, 103, 1528-1533.

7. Mougous, J.D.; Cuff, M.E.; Raunser, S.; Shen, A.; Zhou, M.; Gifford, C.A.; Goodman, A.L.; Joachimiak, G.; Ordonez, C.L.; Lory, S.; et al. A virulence locus of Pseudomonas aeruginosa encodes a protein secretion apparatus. Science 2006, 312, 1526-1530.

8. Tam, V.C.; Serruto, D.; Dziejman, M.; Brieher, W.; Mekalanos, J.J. A type III secretion system in Vibrid cholerae translocates a Formin/Spire hybrid-like actin nucleator to promote intestinal colonization. Cell Host Microbe 2007, 1, 95-107.

9. Filloux, A.; Hachani, A.; Bleves, S. The bacterial type VI secretion machine: Yet another player for protein transport across membranes. Microbiol. SGM 2008, 154, 1570-1583.

10. Shrivastava, S.; Mande, S.S. Identification and functional characterization of gene components of Type VI secretion system in bacterial genomes. PLOS ONE 2008, 3, e2955.

11. Dudley, E.G.; Thomson, N.R.; Parkhill, J.; Morin, N.P.; Nataro, J.P. Proteomic and microarray characterization of the AggR regulon identifies a pheU pathogenicity island in enteroaggregative Escherichia coli. Mol. Microbiol. 2006, 61, 1267-1282.

12. Mougous, J.D.; Gifford, C.A.; Ramsdell, T.L.; Mekalanos, J.J. Threonine phosphorylation post-translationally regulates protein secretion in Pseudomonas aeruginosa. Nat. Cell Biol. 2007, 9, 797-803.

13. Parsons, D.A.; Heffron, F. sciS, an icmF homolog in Salmonella enterica serovar typhimurium, limits intracellular replication and decreases virulence. Infect. Immun. 2005, 73, 4338-4345.

14. Nag, S.; Das, S.; Chaudhuri, K. In vivo induced clpB1 gene of Vibrio cholerae is involved in different stress responses and affects in vivo cholera toxin production. Biochem. Biophys. Res. Commun. 2005, 331, 1365-1373.

15. Schell, M.A.; Ulrich, R.L.; Ribot, W.J.; Brueggemann, E.E.; Hines, H.B.; Chen, D.; Lipscomb, L.; Kim, H.S.; Mrazek, J.; Nierman, W.C.; et al. Type VI secretion is a major virulence determinant in Burkholderia mallei. Mol. Microbiol. 2007, 64, 1466-1485. 
16. Srinivasa Rao, P.; Yamada, Y.; Tan, Y.P.; Leung, K.Y. Use of proteomics to identify novel virulence determinants that are required for Edwardsiella tarda pathogenesis. Mol. Microbiol. 2004, 53, 573-586.

17. Lauriano, C.M.; Barker, J.R.; Yoon, S.S.; Nano, F.E.; Arulanandam, B.P.; Hassettt, D.J.; Klose, K.E. $\mathrm{MglA}$ regulates transcription of virulence factors necessary for Francisella tularensis intraamoebae and intramacrophage survival. Proc. Natl. Acad. Sci. USA 2004, 101, 4246-4249.

18. De Bruin, O.M.; Ludu, J.S.; Nano, F.E. The Francisella pathogenicity island protein IgIA localizes to the bacterial cytoplasm and is needed for intracellular growth. BMC Microbiol. 2007, 7, 1.

19. Foster, P.L. Stress-induced mutagenesis in bacteria. Crit. Rev. Biochem. Mol. 2007, 42, 373-397.

20. Pieper, R.; Huang, S.-T.; Clark, D.J.; Robinson, J.M.; Parmar, P.P.; Alami, H.; Bunai, C.L.; Perry, R.D.; Fleischmann, R.D.; Peterson, S.N. Characterizing the dynamic nature of the Yersinia pestis periplasmic proteome in response to nutrient exhaustion and temperature change. Proteomics 2008, 8, 1442-1458.

21. Poole, K. Stress responses as determinants of antimicrobial resistance in Gram-negative bacteria. Trends Microbiol. 2012, 20, 227-234.

22. Freeman, B.C.; Chen, C.L.; Yu, X.L.; Nielsen, L.; Peterson, K.; Beattie, G.A. Physiological and transcriptional responses to osmotic stress of two Pseudomonas syringaestrains that differ in epiphytic fitness and osmotolerance. J. Bacteriol. 2013, 195, 4742-4752.

23. Gueguen, E.; Durand, E.; Zhang, X.Y.; d'Amalric, Q.; Journet, L.; Cascales, E. Expression of a Yersinia pseudotuberculosis Type VI secretion system is responsive to envelope stresses through the OmpR transcriptional activator. PLoS ONE 2013, 8, e66615.

24. Wang, T.Y.; Ding, J.J.; Zhang, Y.; Wang, D.C.; Liu, W. Complex structure of type VI peptidoglycan muramidase effector and a cognate immunity protein. Acta Crystallogr. Sect. D 2013, 69, 1889-1900.

25. Goldova, J.; Ulrych, A.; Hercik, K.; Branny, P. A eukaryotic-type signalling system of Pseudomonas aeruginosa contributes to oxidative stress resistance, intracellular survival and virulence. BMC Genom. 2011, 12, 437.

26. Weber, B.; Hasic, M.; Chen, C.; Wai, S.N.; Milton, D.L. Type VI secretion modulates quorum sensing and stress response in Vibrio anguillarum. Environ. Microbiol. 2009, 11, 3018-3028.

27. Sarris, P.F.; Skandalis, N.; Kokkinidis, M.; Panopoulos, N.J. In silico analysis reveals multiple putative type VI secretion systems and effector proteins in Pseudomonas syringae pathovars. Mol. Plant Pathol. 2010, 11, 795-804.

28. Nykyri, J.; Niemi, O.; Koskinen, P.; Koivisto, J.N.; Pasanen, M.; Broberg, M.; Plyusnin, I.; Tö rönen, P.; Holm, L.; Pirhonen, M.; et al. Revised phylogeny and novel horizontally acquired virulence determinants of the model soft rot phytopathogen Pectobacterium wasabiae SCC3193. PLoS Pathog. 2012, 8, e1003013.

29. Haapalainen, M.; Mosorin, H.; Dorati, F.; Wu, R.F.; Roine, E.; Taira, S.; Nissinen, R.; Mattinen, L.; Jackson, R.; Pirhonen, M.; et al. Hcp2, a secreted protein of the phytopathogen Pseudomonas syringae pv. tomato DC3000, is required for fitness for competition against bacteria and yeasts. J. Bacteriol. 2012, 194, 4810-4822. 
30. Xie, G.L.; Zhang, G.Q.; Liu, H.; Lou, M.M.; Tian, W.X.; Li, B.; Zhou, X.P.; Zhu, B.; Jin, G.L. Genome sequence of the rice-pathogenic bacterium Acidovorax avenae subsp. avenae RS-1. J. Bacteriol. 2011, 193, 5013-5014.

31. Ibrahim, M.; Shi, Y.; Qiu, H.; Li, B.; Jabeen, A.; Li, L.P.; Liu, H.; Kube, M.; Xie, G.L.; Wang, Y.L. Differential expression of in vivo and in vitro protein profile of outer membrane of Acidovorax avenae subsp. avenae. PLoS ONE 2012, 7, e4965.

32. Garbeva, P.; Silby, M.W.; Raaijmakers, J.M.; Levy, S.B.; de Boer, W. Transcriptional and antagonistic responses of Pseudomonas fluorescens Pf0-1 to phylogenetically different bacterial competitors. ISME J. 2011, 5, 973-985.

33. Russell, A.B.; Peterson, S.B.; Mougous, J.D. Type VI secretion effectors: Poisons with a purpose. Nat. Rev. Microbiol. 2014, 12, 137-148.

34. Shneider, M.M.; Buth, S.A.; Ho, B.T.; Basler, M.; Mekalanos, J.J.; Leiman, P.G. PAAR-repeat proteins sharpen and diversify the type VI secretion system spike. Nature 2013, 500, 350-353.

35. De Maayer, P.; Venter, S.N.; Kamber, T.; Duffy, B.; Coutinho, T.A.; Smits, T.H.M. Comparative genomics of the type VI secretion systems of Pantoea and Erwinia species reveals the presence of putative effector islands that may be translocated by the VgrG and Hcp proteins. BMC Genom. 2011, 12, 576.

36. Hachani, A.; Lossi, N.S.; Hamilton, A.; Jones, C.; Bleves, S.; Albesa-Jove, D.; Filloux, A. Type VI secretion system in Pseudomonas aeruginosasecretion and multimerization of VgrG proteins. J. Biol. Chem. 2011, 286, 12317-12327.

37. Broms, J.E.; Meyer, L.; Lavander, M.; Larsson, P.; Sjostedt, A. DotU and VgrG, Core components of Type VI secretion systems, are essential for Francisella LVS pathogenicity. PLoS ONE 2012, 7, e34639.

38. Gefen, O.; Balaban, N.Q. The importance of being persistent: Heterogeneity of bacterial populations under antibiotic stress. FEMS Microbiol. Rev. 2009, 33, 704-717.

39. Fetar, H.; Gilmour, C.; Klinoski, R.; Daigle, D.M.; Dean, C.R.; Poole, K. mexEF-oprN multidrug efflux operon of Pseudomonas aeruginosa: Regulation by the MexT Activator in response to nitrosative stress and chloramphenicol. Antimicrob. Agents Chem. 2011, 55, 508-514.

40. Aspedon, A.; Palmer, K.; Whiteley, M. Microarray analysis of the osmotic stress response in Pseudomonas aeruginosa. J. Bacteriol. 2006, 188, 2721-2725.

41. Jani, A.J.; Cotter, P.A. Type VI secretion: Not just for pathogenesis anymore. Cell Host Microbe 2010, 8, 2-6.

42. Records, A.R. The type VI secretion system: Amultipurpose delivery system with a phage-like machinery. Mol. Plant Microbe Interact. 2011, 24, 751-757.

43. Lertpiriyapong, K.; Gamazon, E.R.; Feng, Y.; Park, D.S.; Pang, J.; Botka, G.; Graffam, M.E.; Ge, Z.; Fox, J.G. Campylobacter jejuni type VI secretion system: Roles in adaptation to deoxycholic acid, host cell adherence, invasion, and in vivo colonization. PLOS ONE 2012, 7, e42842.

44. Blondel, C.J.; Jimenez, J.C.; Leiva, L.E.; Alvarez, S.A.; Pinto, B.I.; Contreras, F.; Pezoa, D.; Santiviago, C.A.; Contreras, I. The type VI secretion system encoded in Salmonella pathogenicity island 19 is required for Salmonella entericas erotype gallinarum survival within infected macrophages. Infect. Immun. 2013, 81, 1207-1220. 
45. Li, B.; Liu, B.P.; Yu, R.R.; Tao, Z.Y.; Wang, Y.L.; Xie, G.L.; Li, H.Y.; Sun, G.C. Bacterial brown stripe of rice in soil-less culture system caused by Acidovorax avenae subsp. avenae in China. J. Gen. Plant Pathol. 2011, 77, 64-67.

46. Zhang, L.X.; Xie, G.L. Diversity and distribution of Burkholderia cepacia complex in the rhizosphere of rice and maize. FEMS Microbiol. Lett. 2007, 266, 231-235.

47. Liu, H.; Tian, W.X.; Ibrahim, M.; Li, B.; Zhang, G.Q.; Zhu, B.; Xie, G.L. Characterization of pilP, a gene required for twitching motility, pathogenicity, and biofilm formation of Acidovorax avenae subsp. avenae RS-1. Eur. J. Plant Pathol. 2012, 134, 551-560.

48. Ruiz, L.; Sanchez, B.; de los Reyes-Gavilan, C.G.; Gueimonde, M.; Margolles, A. Coculture of Bifidobacterium longum and Bifidobacterium breve alters their protein expression profiles and enzymatic activities. Int. J. Food Microbiol. 2009, 133, 148-153.

49. Livak, K.J.; Schmittgen, T.D. Analysis of relative gene expression data using real-time quantitative PCR and the $2^{-\Delta \Delta C t}$ method. Methods 2001, 25, 402-408.

(C) 2015 by the authors; licensee MDPI, Basel, Switzerland. This article is an open access article distributed under the terms and conditions of the Creative Commons Attribution license (http://creativecommons.org/licenses/by/4.0/). 